\title{
MULE AND IMITATIVE FULŪS OF EGYPTIAN COINS \\ FROM BILĀD AL-SHĀM IN THE EARLY ISLAMIC ERA \\ TYPOLOGICAL STUDY
}

BY

\section{Mohammad Younis}

Associate Professor of Islamic Numismatics, Fayoum University, Egypt.

[AR]

الفلوس الهجين والمقلدة للنقود المصبرية من بلاد الشام فى العصبر الإسلامى المبكر

يهدف هذا البحث إلى دراسة النقود النحاسية والبرونزية المقلدة للفلوس التى كانت تُضرب في مصر في العصر الإسلامى المبكر، والتى كانت

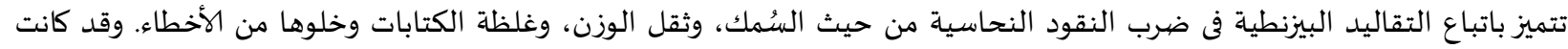

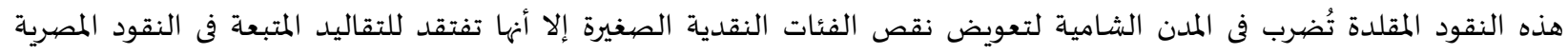

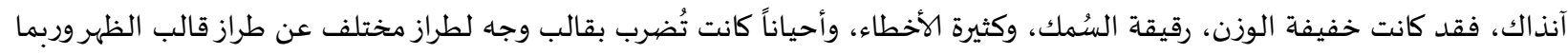

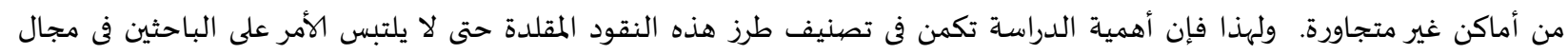

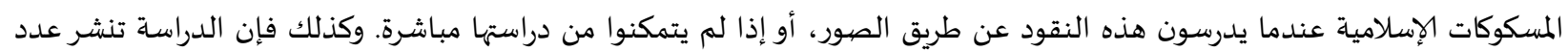

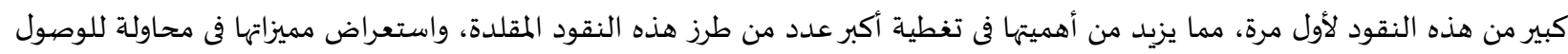

$$
\text { إلى تأريخها وتحديد أماكن سكهاد }
$$

[EN] The Egyptian copper coins were of highly importance in the trades of monetary circulation in the early Islamic state. They maintained the traditions of Byzantine minting techniques, like a marked heaviness in weight and thickness in size, and ruggedness in inscriptions. Groups of imitative light copper and bronze coins have emerged, bearing those features of the Egyptian fulüs, but in shape only, they differ in minting techniques, size, weight and thickness. Some of them are hybrid imitated resemble the inscriptions of the Egyptian copper coins in one side, and the characters of the Bilād al-Šăm inscriptions on the other side. This paper contributes imitative coins of Egyptian Fulūs from Bilād al-Šām, some of them are unpublished, in an attempt to identify the source of the imitation and monitor the most important features.

KeYwORDs: Egyptian Fulūs, imitative Fulūs, mule coins, Fusțāț, Atrīb. 


\section{INTRODUCTION}

When Muslims armies conquered Egypt in $18 \mathrm{AH} / 639 \mathrm{AD}$, the common circulating copper coins were the 12-nummia piece minted by Heraclius (r. 610-641 AD) in Alexandria. There is no doubt that those copper coins of Heraclius, and later of his successor Constants II (r. 641-668 AD) continued to circulate for several years. Despite the high activity of the Egyptian mints in producing coins at that time, the numismatic evidence states that there were no transitional types for Egypt comparable to those issued in Syria and Palestine ${ }^{1,}$ Egypt began issuing coins directly with Arabic inscriptions, and coins emerged which hold the names of the Egyptian mints.

The Egyptian bronze and copper coins of reformed Arab types struck during the Umayyad and early ${ }^{c} A b b \bar{a} s \bar{i} d$ periods can be easily distinguished by their characteristic technique of minting, as the new authorities established a mint in al-Fustāt along the line with Egyptian Byzantine minting traditions. These coins are marked by their heaviness in weight, thickness in size, and ruggedness in inscriptions. Sub-mints were also established in Atrīb, Fayyūm and Ahnās, while the mint of Alexandria continued issuing coins intermittently throughout the Islamic era in Egypt.

Groups of imitative light copper coins have turned up, bearing features of the Egyptian fulūs in their design. But they differ in minting techniques, size, weight and thickness. Some of them are mules. That means one side resemble the inscriptions of the Egyptian copper coins, and the other side imitates a different Syrian copper coin type of another mint.

\section{PREVIOUS STUDIES}

In 1980, Lutz Ilisch published his invaluable contribution on the Umayyad and 'Abbāsìd copper coins of $\operatorname{Hims}^{2}$, he mentioned to the small copper coins which were circulated in Syria especially during the periods of the absence of the ${ }^{c} A b b \bar{a} s \bar{\imath} d$ fulus after the decline of the Umayyads. In 2000, Nikolaus Schindel ${ }^{3}$, indicated to the Egyptian imitative copper coins, according to the previous indications of Lutz Ilisch without any more information.

- In 2003, Stefan Heidemann", published a group of Syrian mules of copper coins imitation coins of al-Kūfa. A one group among them were mules with Egyptian coppers. Those imitation could be dated to the year between 167 and the $180 \mathrm{AH}$.

\footnotetext{
${ }^{1}$ I presented this contribution in the $3^{\text {rd }}$ symposium of Money and monetary circulation in the Mediterranean countries, Antalya 2017. MILES 1958: 471- 472.

${ }^{2}$ ILISCH 1980: 23-30.

${ }^{3}$ SCHINDEL 2000: 52-53.

${ }^{4}$ HEIDEMANN 2003: 154.
} 


\section{The PRESENT STUDY}

This paper contributes more examples of these imitative light copper coins, some of them are unpublished, in an attempt to identify the source of the imitation and monitor the most important features.

\section{PROPOSED CLASSIFICATION}

The prototype of the imitative types $1,2, \& 3$ is the most prolific type of the Umayyad Egyptian copper coins. It is particularly interesting because it used the Arabic word «Mișr» which denoted on the one side in «all embracing town», in the meaning of a Muslim garrison city, and in particular the name of the Egyptian province. The other side has the name of that «military city» the specific mint name Fusțāț. Probably, it is to be read «Mișr al-Fusțāt'» the military city Fustât [FIGURE 1] $]^{5}$.

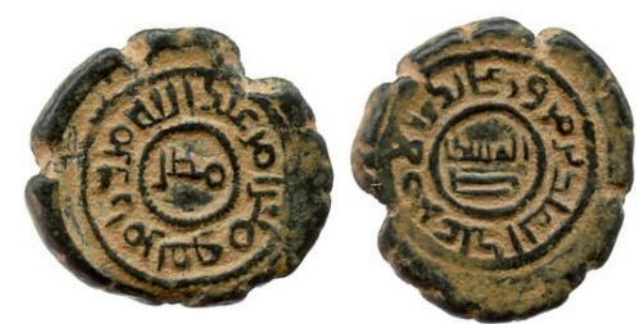

[FIGURE 1].WILKS \& CURTIS: Auct. 11 № 45

Although these coins do not bear dates, they are closely datable. They carry the names of the last Umayyad Caliph, Marwān II (127-132 AH and of 'Abd al-Malik ibn Marwān, the finance director of Egypt from Rağab 131-Ğumādā I 132 AH.

Type 1 A (Miṣr al-Fusțāt type)

bv. Within a dotted circle مصد الله عبد الملك بن مروان Marginal legends, عصر ط

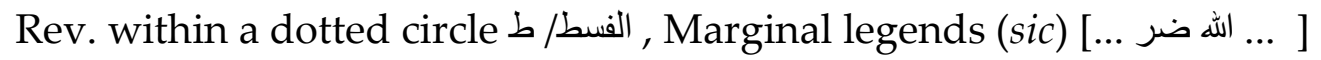

- Walker 1956: № $.910(1.16 \text { g. } 14 \mathrm{~mm})^{6}$

- SNAT III 2017: № 11197 (1.15 g. $15 \mathrm{~mm}, 8 \mathrm{~h})$

- SNAT III 2017: № 1196 (0.70 g. 13 mm, 9h)

- Universität Hamburg, photo Nro. SB $12857(0.92 \mathrm{~g}, 15 \mathrm{~mm}, 7 \mathrm{~h})^{7}$ [FIGURE 2]

- Universität Hamburg, photo $\mathrm{N}^{\mathrm{r}}$. SB 12855 (0.79 g, $\left.15 \mathrm{~mm}, 2 \mathrm{~h}\right)$

- Universität Hamburg, photo №o. SB 12856 (0.93 g, 14 mm, 3h)

\footnotetext{
${ }^{5}$ MILES 1958: 477; WILKS \& CURTIS: Auct. 11 Nㅗ⿳o .45 (6.78 g).

${ }^{6}$ WALKER 1956: 910

${ }^{7}$ The photos of the coins with the SB numbers were provided by STEPHAN HEIDEMANN.
} 

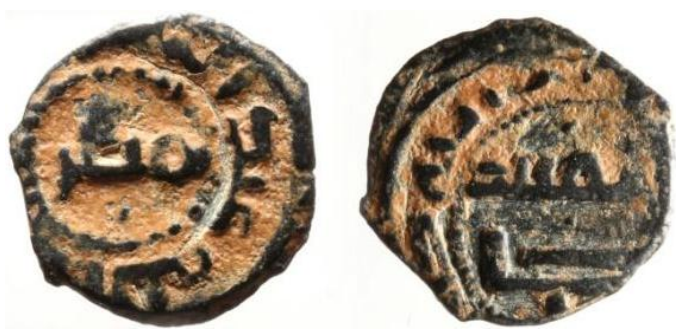

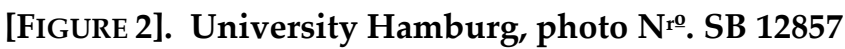

\section{Type 2 A (Miṣr Type)}

The coins of type two are frequently die linked, suggesting that they come from one single workshop.

Obv. Within a circle مبد الله عبد الملك بن مروان Marginal legends مصر اللهر

Rev. within a circle محمد رسول اله] [ لا إله (اله) / إلا اله/ وحده , Marginal legends

- SNAT III 2017: №o. 1189 (2.47 g, 19 mm, 11h) ${ }^{8}$ [FIGURE 3]

- Universität Hamburg, photo Nro . SB 12859 (1.70 g, 18 mm, 10h; same obverse die as SB 12858, 12860, 12863and Zeno, $\mathrm{N}$ ro . 1646)

- Universität Hamburg, photo Nrº. SB 12860 (1.92 g, 18 mm, 2h; same obverse die as 오 SB 12858, 12859, 12863and Zeno, N. 1646)

- Zeno: № ${ }^{\text {o }} 1646$ (16 mm; same obverse die as SB 12858, 12859, 12860 \&12863)
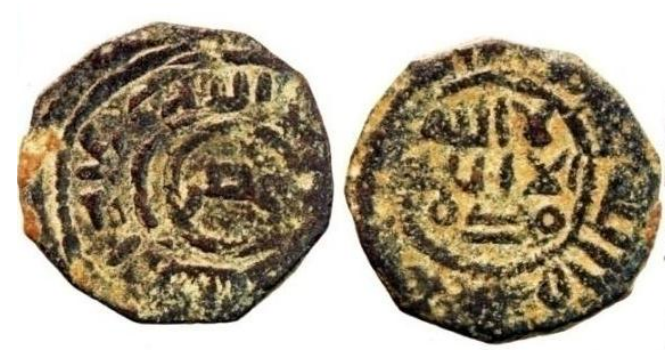

[FIGURE 3]. SNAT III 2017: N Nro 1189

\section{Type 2 B}

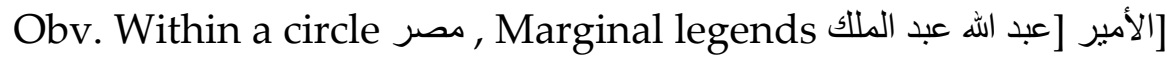

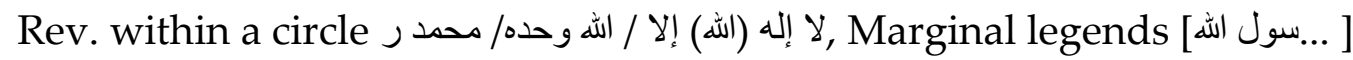

- Goussous 2014: 61 Nro. 2 (2.00 g, 17 mm, 6h)

- SNAT III 2017: №o․ 1186 (1.70 g, $18 \mathrm{~mm}, 5 \mathrm{~h})$ [FIGURE 4]

- $\quad$ SNAT III 2017: Nro. 1187 (1.61 g, 18 mm, 10h)

- Universität Hamburg, photo $\mathrm{N}^{\mathrm{r}}$ ㅇ. SB 12858 (1.85 g, $18 \mathrm{~mm}$, 4h; same obverse die as SB $12859,12860 \& 12863)$

\footnotetext{
${ }^{8}$ YOUNIS 2017: 1198
} 


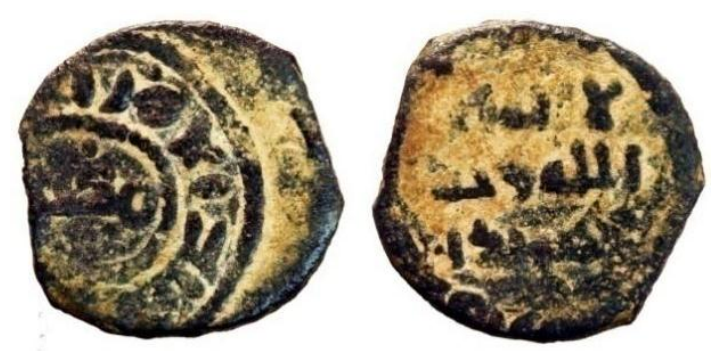

[FIGURE 4]. SNAT III 2017: №o. 1186

\section{Type $2 \mathrm{C}$}

Obv. Within a circle مصر , Marginal legends الأمبر [بد الله عبد الملك / رمبر ]

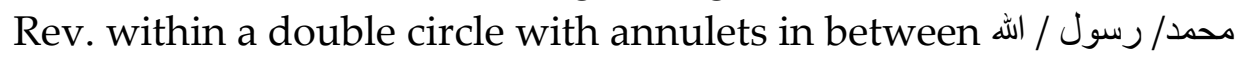

- SNAT III 2017: №. 1188 ( $2.28 \mathrm{~g}, 19 \mathrm{~mm}, 5 \mathrm{~h}$ ) [FIGURE 5]

- Universität Hamburg, photo $\mathrm{N}^{\mathrm{r}}$ ㅇ․ SB 12863 (1.50 g, $17 \mathrm{~mm}$, 7h; same obverse die as SB 12858,$12859 ; 12860)$

- Universität Hamburg, photo Nro. SB 12864 (1.21 g, 14 mm, 6h)

- Zeno: Nrº. 111809 (1.15 g, 16 mm)
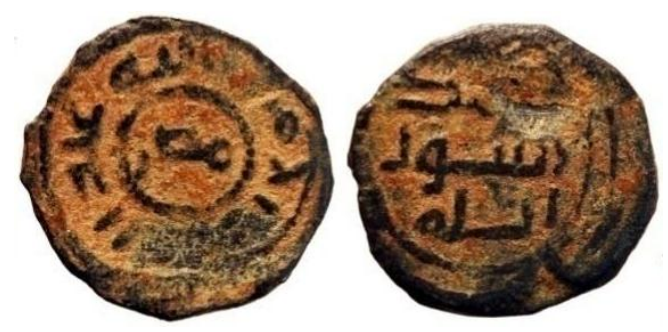

[FIGURE 5]. SNAT III 2017: Nº. 1188

\section{Type 2 D}

Obv. Within a circle مصر above and a crescent below , Marginal legends ...] Rev. عبد الملك / بن يزيد, marginal legends ...

- SNAT III 2017: №o. 1190 (0.66 g, 13 mm, 9h) [FIGURE 6]

'Abd al-Malik Ibn. Yazīd (133-141 h.) issued a considerable number of glass weights and vessel stamps, and his career is well documented not only by the coins and glass weights, but also in the historical literature. In this case both sides referred to Egyptian types.
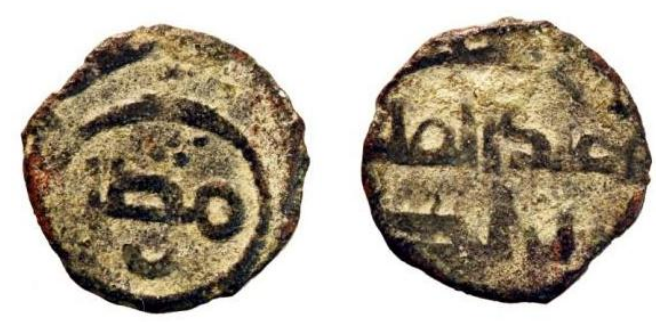

[FIGURE 6]. SNAT III 2017: Nrōo. 1190 


\section{Type $2 \mathrm{E}$}

Obv. Within a circle مصر , Marginal legends الأمير عبد الله عبد الملك

و ضرب هذا الفلس بحمص Rev. within a circle jerboa to right, marginal legends

- SNAT III 2017: №o. 1191(1.00 g, 14 mm, 3h) [FIGURE 7]

- Tübingen, inv. Nㅗㅇ. AC9 B4 $(1.58 \mathrm{~g}, 15 \mathrm{~mm}, 7 \mathrm{~h})$

- Universität Hamburg, photo Nㅗ․ SB 12853 (1.05 g, 16 mm, 5h)

- Universität Hamburg, photo №. . SB 07433 (1.12 g, 14 mm)

Marwān ibn Bišr, governor of Himș in later 130s AH.
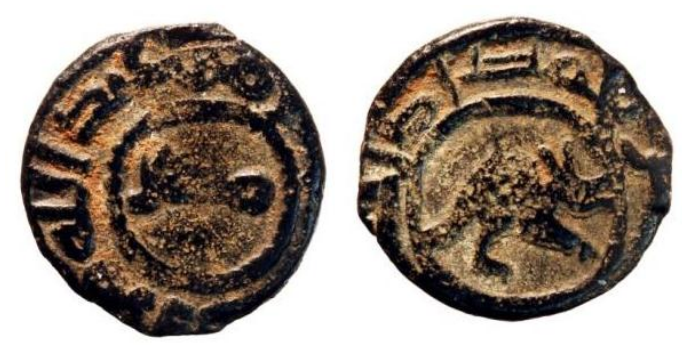

[FIGURE 7]. SNAT III 2017: №. 1191

\section{Type $2 \mathrm{~F}$}

Obv. Within a dotted circle مصر Marginal legends الأمير عبد [اله عبد المبلك ]

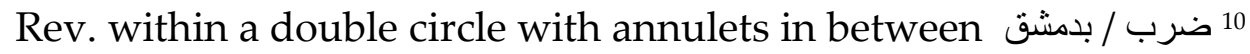

- Zeno: Nro. 158153 (1.19 g, 15.5 mm) [FIGURE 8]
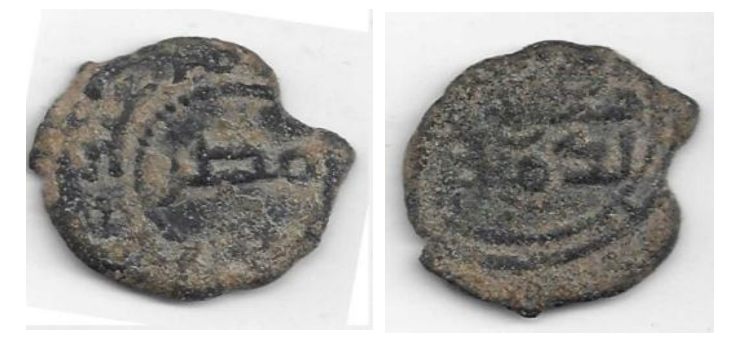

[FIGURE 8]. ZENO: №. 158153

\footnotetext{
${ }^{9}$ For more information and examples about the coinage of the jerboa from Hims, see: ILISCH 1980: 28; WALKER 1956: №oss 804-806.

${ }^{10}$ For more about the prototype of this coin, see: WALKER 1956: $\mathrm{N}^{\mathrm{r}} \mathrm{o}$ B.46, PL.XXVII
} 


\section{Type 3 A (AL-FUSṬ̂̄Ṭ type)}

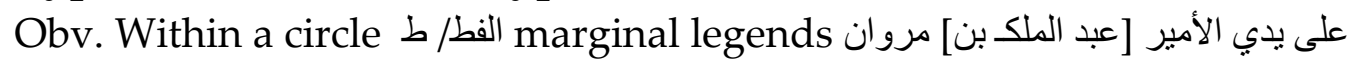
لا إله / إلا اله / وحده Rev. within a double circle with annulets in between

- Universität Hamburg, photo Nㅗㅇ. SB 12865 (1.13 g, 15 mm, 1h) [FIGURE 9]
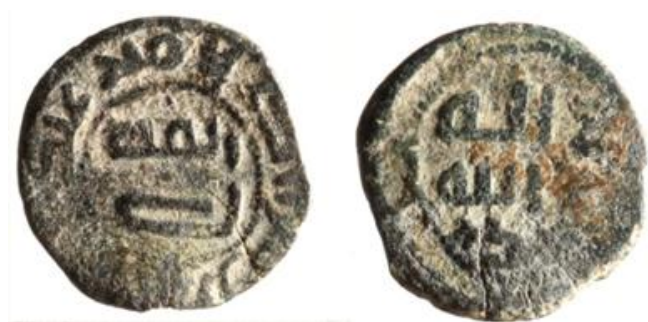

[FIGURE 9].Uni. Hamburg, photo no. SB 12865

\section{Type 3 B}

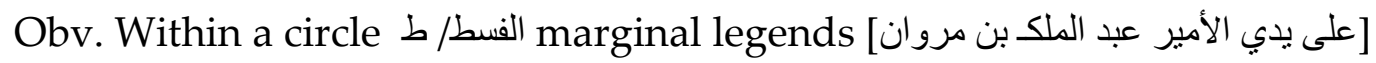
لا إله / إلا اله /وحده Rev. within a double square

- Universität Hamburg, photo Nro. SB 12854 (3.34 g, 16 mm, 4h) [FIGURE 10]

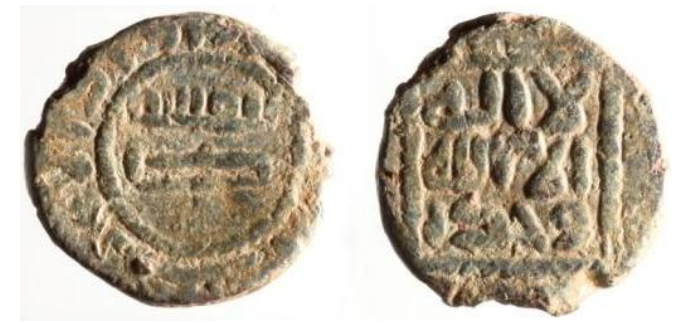

[FIGURE 10]. University Hamburg, photo N Nº. SB 12854

\section{Type $3 \mathrm{C}$}

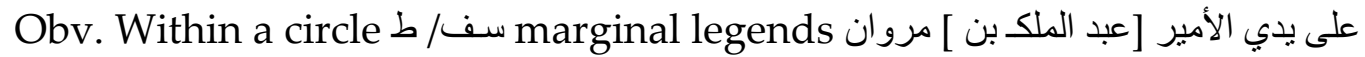

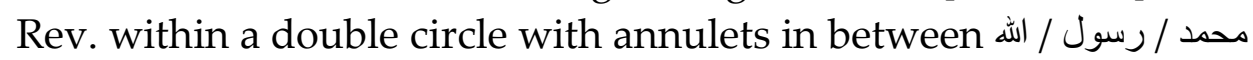

- SNAT III 2017, №. 1194 (1.59 g, 14 mm, 9h) [FIGURE 11]

- ANS: inv. №. 1991.3. 199 (0.899 g, 13 mm)

- ZENO: №. 100915 (1.29 g, 14 mm)
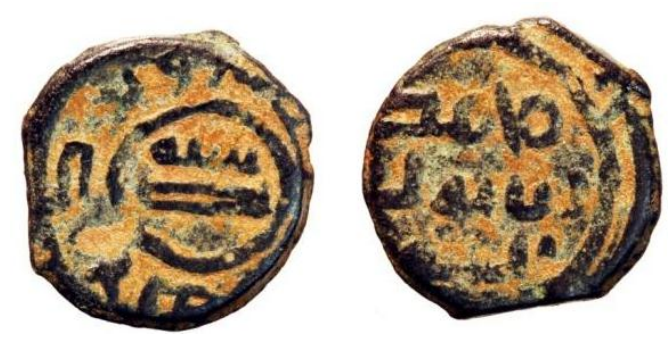

[FIGURE 11]. SNAT III 2017, №º. 1194 


\section{Type $3 \mathrm{D}$}

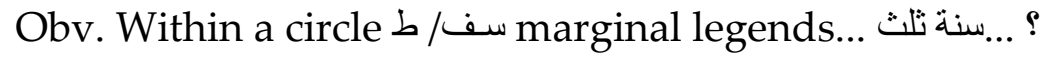

Rev. within a dotted square / محد / رسول / اله

- SNAT III 2017: № 1192 (1.11 g, 15 mm, 5h) [FIGURE 12]

- SNAT III 2017: Nro. 1193(1.19 g, 14 mm, 12h)
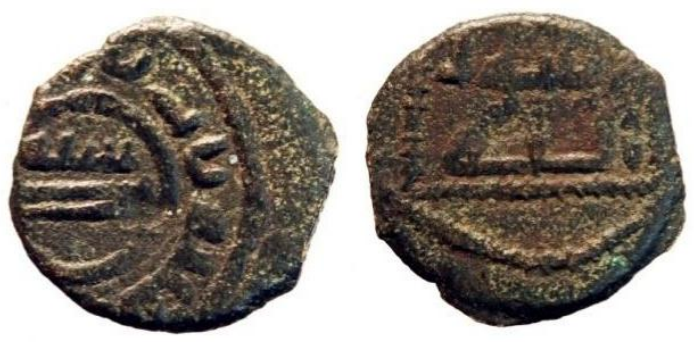

[FIGURE 12]. SNAT III 2017: No․ 1192

\section{Type $3 \mathrm{E}$}

Obv. Within a dotted circle سف marginal legends ... Rev. within a circle .... / سعيد أ / صلحه اله اله

- SNAT III 2017: №o. 154 (2.36 g, 14 mm, 11h) [FIGURE 13]
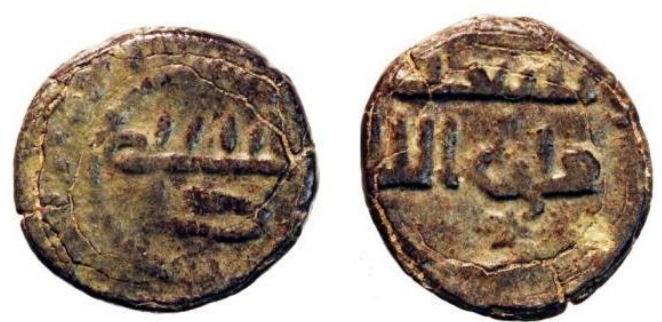

[FIGURE 13]. SNAT III 2017: Nºo. 154

\section{Type 3 F}

Obv. Within a dotted circle سف مروان ... marginal legends Rev. Brockage of the obverse

- SNAT III 2017: Nro. 1195 (1.36 g, 15 mm, 12h) [FIGURE 14]
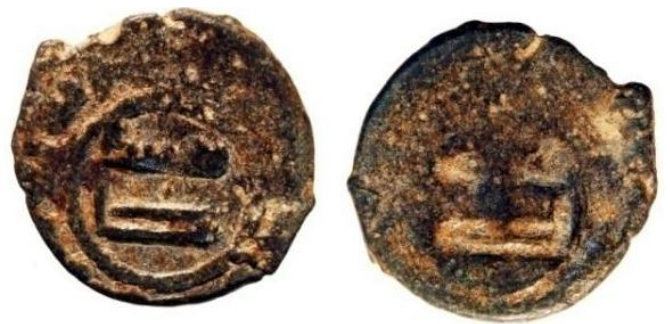

[FIGURE 14]. SNAT III 2017: Nº. 1195 


\section{Type 4 A (Muḥammad ibn Sa ${ }^{\prime} \mathbf{1} d$ Type $)^{11}$}

Muhammad ibn Sa'īd ibn 'Uqba was finance director of Egypt, and possibly also governor, for some time- if not the entire period between 152-157 AH./ 769-774 AD. His name can be found on glass weights and vessel stamps, and also in a papyrus document dated $153 \mathrm{AH}{ }^{12}$, where he used the title amir.

/ Obv. Within a circle

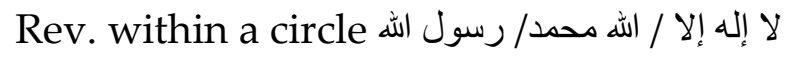

- Snat III 2017: №ro. 153 (1.84 g, 15 mm, 5h) [FiguRE 15]

- Snat III 2017: №ro. $152(2.09$ g, 16 mm, 6h)

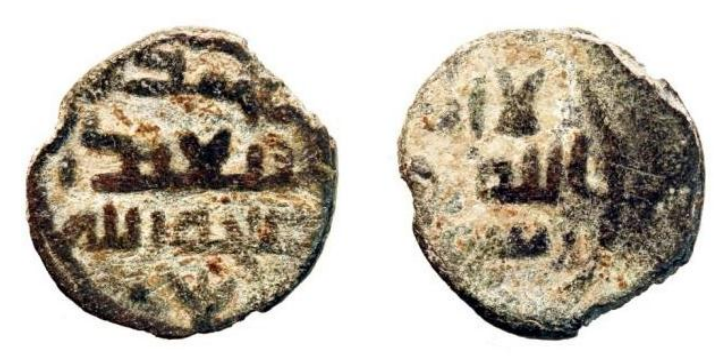

[FIGURE 15]. SNAT III 2017: Nº 153

\section{Type 5 A (Mațar Type) $)^{13}$}

Mațar was a client (mawlā) of the caliph al-Manșūr, the dates of his governorship are uncertain (159 AH according to one tradition ${ }^{14}$, 157-159 AH /773-776 AD according to another ${ }^{15}$ )

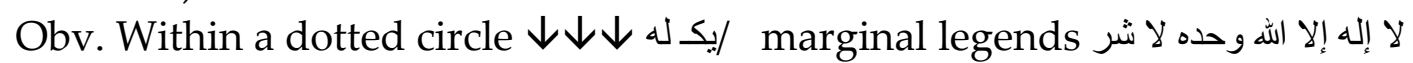

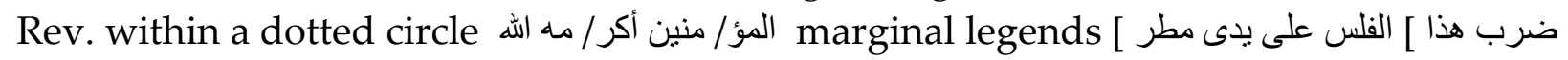
[مولى أمير

- SNAT III 2017: Nro. 169 (3.29 g, 14 mm, 8h) [FIGURE 16]

- SNAT III 2017: N ㄲo. 168 (3.81 g, 17 mm, 12h)

- Universität Hamburg, photo №ro. SB 13458 (2.49 g, 16 mm, 5h). The reverse of this coin is from the same mater to produce the mould as $\mathrm{Nr}^{\circ}$. SB 13457, confirming that they are produced at the same time.

\footnotetext{
${ }^{11}$ For more about the prototype of this coin. MILES 1958: Nㅗ을 15b; FAHMI 1965: Nㅗㅇㅡ 2866; YOUNIS 2017: Nross $147-151$.

${ }^{12}$ FAHMI 1957: 118-122.

${ }^{13}$ For more about the prototype of this coin, see: MILES 1958: Nㅗㅇ․ 16; NÜTZEL 1898: N ${ }^{\text {ro. }}$. 2253-4; LAVOIX

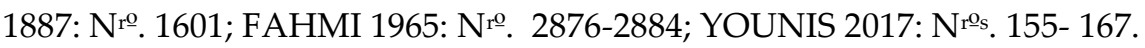

${ }^{14}$ ZAMBAUR 1927: 27.

${ }^{15}$ MILES 1958: 487.
} 

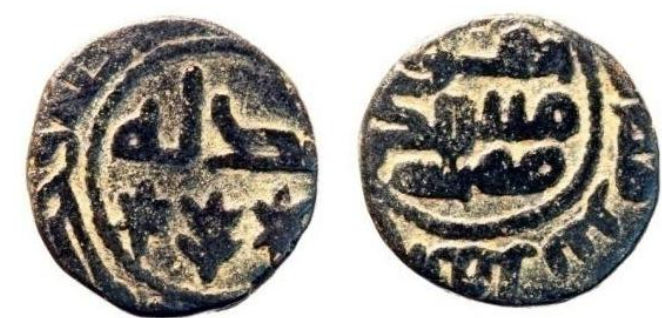

[FIGURE 16].SNAT III 2017: №o․ 169

\section{Type 5 B (Küfa Types I-II) $)^{16}$}

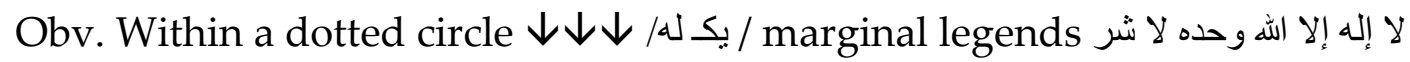

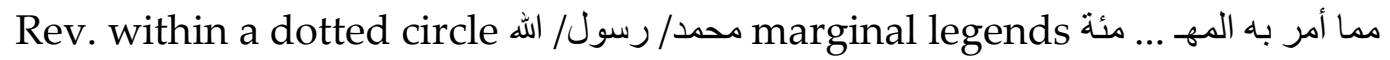

- Universität Hamburg, photo N ㄲo. SB 04532 (published in HEIDEMANN 2003a, 154 $\mathrm{N}$ ro. SB 532, illustration 312, PL.54; $2.46 \mathrm{~g}, 17 \mathrm{~mm}, 1 \mathrm{~h}$; the reading of the marginal legend is taken from this coin) [FIGURE 17]

- Universität Hamburg, photo N Nro. SB 04533 (published in HEIDEMANN 2003a, 154 Nro. SB 533 illustration p. 312 PL.54; $2.95 \mathrm{~g}, 18 \mathrm{~mm}, 5 \mathrm{~h})$

- MorTOn \& EDEN, Auct. 76, December 15, 2015, Nº․ 328 (2.77 g)
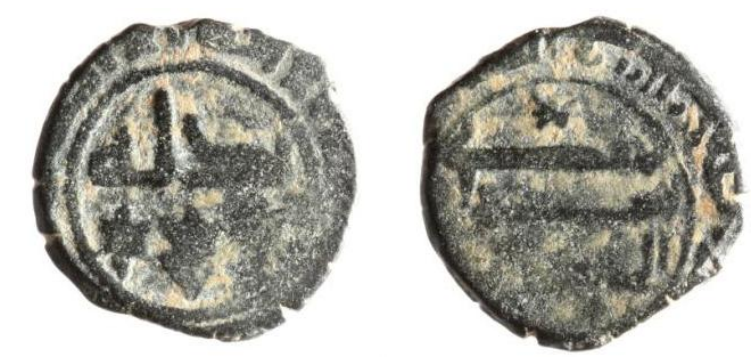

[FIGURE 17]. University Hamburg, photo №ํo. SB 04532

\section{Type 5 C: Unknown Prototype from the Time of Hārūn al-Rashīd.}

Obv. within a dotted circle إ إله إله وحده/ لا شريك له , marginal legends: off flan. The prototype for this obverse is from the time of Hārūn al-Rashīd, either Qinnasrīn 181, alRāfiqa 181 or a similar coin.

ضرب هذا الفلس على يدى مطر [ marginal legends , المؤ/ منين أكر / مه اله Rev. within a dotted circle [مولى أمير]

- $\quad$ Universität Hamburg, photo Nro. SB 13457 (2.59 g, 16 mm, 8h) [FIGURE 18]. This coin shares the same mater for the mould as SB 13458.

\footnotetext{
${ }^{16}$ The classification of the Küfa type follows HEIDEMANN 2003a \& b.
} 


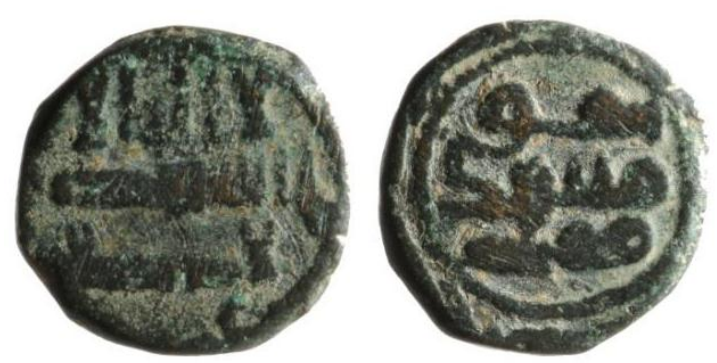

[FIGURE 18]. University Hamburg, photo $\mathrm{N}^{\text {ro }}$. SB 13457

\section{Type 6 A (Ibrāhīm ibn Șāliḥ Type) $)^{17}$}

Governor of Egypt (165-167 AH)

Obv. Within a circle مما أمر به / الأمير /....

Rev. within a circle إبر اهيم / بن صلح أكر / مه اله a crescent above reverse legends

- Nicol 2009: № 1580 (1.86 g, 9h)

- SNAT III 2017: Nro. $182(1.78 \mathrm{~g}, 15 \mathrm{~mm}, 12 \mathrm{~h})$

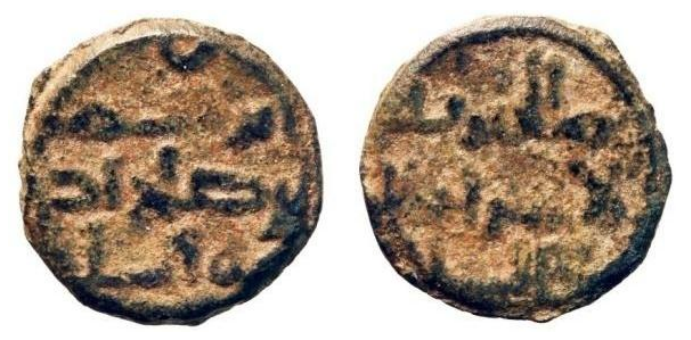

[FIGURE 19]. SNAT III 2017: №. 182

\section{Type 6 B}

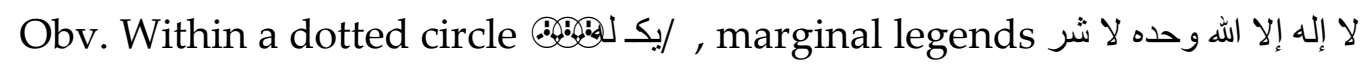

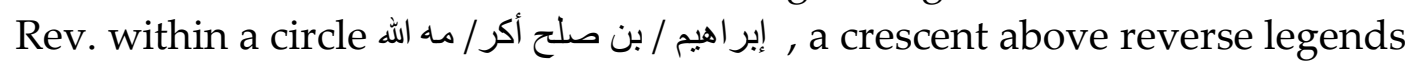
- SNAT III, Nro. 183 (2.17 g, 16 mm, 9h) [FiguRe 20].
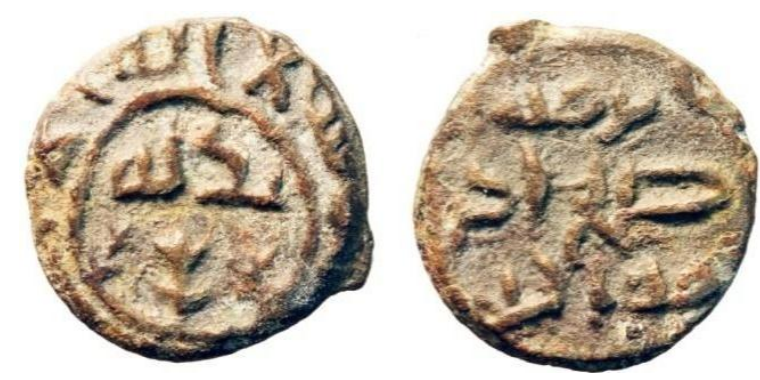

[FIGURE 20]. SNAT III, № ${ }^{\circ} .183$

\footnotetext{
${ }^{17}$ For more about the prototype of this coin, see: YOUNIS 2017: NrOs 179-181.
} 


\section{DATING}

The imitations show two groups. The first group (types 1 to 3 ) are lightweight fulūs mostly cast. The prototype is mostly coins of the governor 'Abd al-Malik ibn Marwān (r. $132 \mathrm{AH} /$. It suggests that the casts are later, perhaps between the 130s and 150s. The mules are coins from Hims and Damascus. It can be assumed that these coins were minted within Syria. Especially the coins of type 2 are interlinked. The second group centers on coins of the governor Matar (r. 157-159 AH/773-776 AD). Also here are links to coins which were produced in the 170s and 180s (Küfa type coins and coins from the time of Hārūn al-Rashīd. Mules with Küfa coins types also exist with coins of Qinnarsīn 169 AH., Nașībīn 181 AH., al-Rāfiqa 181 AH./ and Dimashq $183 \mathrm{AH}$. The mules and imitations of Egyptian type coins belong also to this context $^{18}$. While the sources for both groups are Egyptian copper coins, they are likely to be produced in Bilād al-Šàm.

\section{CONCLUSION}

This paper presented the imitative copper coins of the Egyptian fulūs in the early Islamic era, the original Egyptian fulūs followed the Byzantine traditions of minting copper coins, like a marked heaviness in weight and thickness in size, and ruggedness in inscriptions. Groups of imitative light copper and bronze coins have emerged, bearing those features of the Egyptian fulūs, but in shape only, they differ in minting techniques, size, weight and thickness. Some of them are hybrid imitated resemble the inscriptions of the Egyptian copper coins in one side, and the characters of the Biläd al$\check{S} \bar{a} m$ inscriptions on the other side. This paper contributes imitative coins of Egyptian Fulūs from Bilād al-Šàm in a typological system, some of them are unpublished, in an attempt to identify the source of the imitation and monitor the most important features.

\section{ACKNOWLEDGMENT}

I owe my gratitude to Stefan Heidemann (Universität Hamburg) \& Lutz Ilisch (EberhardKarls Universität Tübingen) for their generous help by providing me with most of the photos of this paper.

\footnotetext{
${ }^{18}$ For the mule of al-Rāfíqa; HEIDEMANN, 2003b: 120 No․ II-IV/K1,154.
} 


\section{Mohammad Younis}

\section{BIBLIOGRAPHY}

AL-KINDĪ, M.B. YŪSUF: Kitāb al-wulāh wa kuttāb al-quḍ̄h, Beirut (al-Abā' al-Yasūciyīn Press) 1908.

BACHARACH, J. \& AMIN AWAD, H.: «The Early Islamic Bronze Coinage of Egypt: Additions», Near Eastern Numismatics, Iconography, Epigraphy and History, Studies in Honor of George C. Miles Beirut (American University of Beirut) 1974, 185-192.

BACHARACH J. (ed.), Fusțāt Finds, Beads, Coins, Medical Instruments, Textiles, and Other Artifacts from the Awad Collection, Cairo (AUC Press) 2002.

FAHMĪ, A.: Șinağ al-sakka fì fă̆r al-Islām, Cairo (Egyptian National Library Press) 1957.

FAHMİ, A.: Mausū'at al-nuqūd al-'arabiya wa-'ilm al-munamnamät I, făgr al-sakka al-'arabìya, Cairo (Egyptian National Library Press) 1965.

GOUSSOUS N., ALZUOD H. \& NAGHAWY A.: «Inedited and Rare Islamic Coins, Amman (Jordan Ahli Bank Numismatic Museum) 2014.

HEIDEMANN, S.: «Der klein Geldumlauf in der Ğazīra in früh-'abbāsidischer Zeit und die Münzemissionen aus al-Kūfa», in: S. HEIDEMANN $\mathcal{E}$ A. BECKER (eds.), Raqqa II. Die islamische Stadt, Mainz Am Rhein, 2003, 141-167.

HEIDEMANN, S.: «Die frühe Münzprägung von ar-Raqqa/ar-rāfiqa als Dokumente zur Geschichte der Stadt », in: S. Heidemann \& A. Becker (eds.), Raqqa II. Die islamische Stadt, Mainz Am Rhein, 2003, $115-140$.

ILISCH, L.: «Die umayyadischen und cabbāsidischen Kupfermünzen von Hims Versucheiner Chronologie», Münstersche Numismatische Zeitung 10, 1980, 23-30.

KAWATOKO, M.: «On the Coins Found at al-Fusțāț», Senri Ethnological Studies 55, (2001) 55-71.

LAVOIX, H.: Catalogue des monnaies musulmanes de la Bibliothèque Nationale I, Khalifes Orientaux, Paris (Imprimerie Nationale) 1887.

MILES, G.: The Early Islamic Bronze Coinage of Egypt, New York (Centennial Publication of the American Numismatic Society) 1958, 471-502.

MORTON \& EDEN: Auction 76, London, Dec. 15, 2015.

NICOL, N.: Sylloge of Islamic Coins in the Ashmolean, vol.2, Early Post-reform Coinage, Oxford (Spink \& Son) 2009.

NÜTZEL, H.: Königliche Museen zu Berlin, Katalog der orientalischen Münzen, vol. 1, (W. Spemann) 1898.

REIS, L. , SCHINDEL, N.: «Von Mäusen und Menschen: Frühislamische Bronzemünzen mit bildlichen Darstellungen», Money Trend 4 , 1999, 56-61

REIS, L. , SCHINDEL N. \& WELLENHOFER, S.: « Der früheste cabbāsidische Münztyp aus Ägypten», Mitteilungen der Österreichischen Numismatischen Gesellschaft 44/3, 2004, 101-106.

SCHINDEL, N.: « Einige omaijadische Kupfermünzen II », Money Trend 9/2000, 52-53.

WALKER, J.: A Catalogue of the Arab-reform Umaiyad Coins, Oxford (Oxford University Press) 1956.

YOUNIS, M.: Sylloge Numorum Arabicorum Tübingen (SNAT), III Egypt, Berlin (Ernest Wasmuth Verlag Tübingen) 2017.

ZAMBAUR, E.: Manuel de Généalogie et de Chronologie pour l'historie de L'Íslam, Leipzig (Buchdrurtie W.Hoppe) 1927. 